\title{
Analisis Nisbah Bagi Hasil Pembiayaan Mudharabah pada Bank Syariah Mandiri KCP Sengkang
}

\author{
Ainul Hikmah \\ Institut Agama Islam Negeri (IAIN) Bone \\ ainulhikmah@yahoo.co.id
}

Nahariah

Sekolah Tinggi Agama Islam (STAI) Al -Furqan Makassar

nahariah@gmail.com

\begin{abstract}
The purpose of this research is to understand the meaning of revenue sharing, the method of calculating revenue sharing and the profit sharing advantage on mudharabah financing in independent Islamic banks. The results of the study show that Revenue Sharing is a profit sharing system that is calculated from the total revenue of fund management without being reduced by the cost of managing funds. So if the bank and the customer use the mudharabah scheme in carrying out working capital financing, if the business is profitable, then it must be divided based on the profit sharing portion. The advantages of mudharabah financing sharing ratio in Bank Syariah Mandiri Sengkang KCP is to be able to increase investment in third party funds on Islamic banks because if the bank uses a profit sharing calculation system based on revenue sharing where profit sharing will be distributed from total revenues before deducting with costs, the likelihood that there will be a profit sharing rate that will be received by the owner of the fund will be greater than the prevailing market interest rate.
\end{abstract}

Keywords: Revenue Sharing, Profit Sharing Ratio, Mudharabah Financing

\begin{abstract}
Abstrak
Tujuan Penelitian ini untuk mengetahui pengertian revenue sharing, metode perhitungan revenue sharing dan keunggulan nisbah bagi hasil pada pembiayaan mudharabah pada bank syariah mandiri. Hasil penelitian menunjukkan bahwa Revenue Sharing merupakan sistem bagi hasil yang dihitung dari total pendapatan pengelolaan dana tanpa dikurangi dengan biaya pengelolaan dana. Jadi jika bank dan nasabah menggunakan skim mudharabah dalam menjalankan pembiayaan modal kerja maka jika usahanya untung, maka harus dibagi berdasarkan porsi bagi hasil. Adapun keunggulan nisbah bagi hasil (revenue sharing) pembiayaan mudharabah pada Bank Syariah Mandiri KCP Sengkang adalah dapat meningkatkan investasi dana pihak ketiga pada bank syariah karena jika bank menggunakan

Jurnal Ilmiah Al Tsarwah Program Magister Program Studi Ekonomi Syariah


sistem perhitungan bagi hasil berdasarkan revenue sharing dimana bagi hasil akan didistribusikan dari total-total pendapatan sebelum dikurangi dengan biaya-biaya maka kemungkinan yang akan terjadi akan tingkat bagi hasil yang akan diterima oleh pemilik dana akan lebih besar dibandingkan dengan tingkat suku bunga pasar yang berlaku.

Kata kunci : Revenue Sharing, Nisbah Bagi Hasil, Pembiayaan Mudharabah

\section{PENDAHULUAN}

Perbankan merupakan lembaga keuangan yang menghimpun dana dari masyarakat guna memenuhi kebutuhan dana pihak yang membutuhkan, baik untuk kegiatan produktif maupun konsumtif. ${ }^{1}$ Selain itu juga ada jasajasa perbankan lain yang disediakan oleh bank syariah. Dalam melaksanakan kegiatan penghimpunan dana, bank syariah menerima simpanan dari masyrakat, sedangkan dalam penyaluran dana bank syariah memberikan jasa dalam bentuk pembiayaan. Pembiayaan pada bank syariah merupakan salah satu tulang punggung kegiatan perbankan karena dari situlah perbankan dapat bertahan hidup dan berkembang. Dalam melaksanakan kegiatan penyaluran dana, bank syariah melakukan investasi dan pembiayaan. ${ }^{2}$

Salah satu keunikan produk perbankan syariah adalah adanya fasilitas pembiayaan dengan pola bagi hasil. Pola pembiayaan ini salah satunya adalah pembiayaan mudharabah. Pembiayaan mudharabah merupakan perkongsian yang salah satu pihak bertindak menyediakan dananya (shahibul maal), sedangkan yang lainnya menyediakan keahlian dan bertindak sebagai mudarib. ${ }^{3}$

${ }^{1}$ Kasmir, Dasar-dasar Perbankan, (Cet. 1; Jakarta: PT. Raja Graindo Persada, 2002), h. 2.

${ }^{2}$ H. Syukri Iska, Sistem Perbankan Syariah di Indonesia, (Cet. 1; Yogyakarta: Fajar Media Press, 2012), h. 45.

${ }^{3}$ H. Syukri Iska, Sistem Perbankan Syariah di Indonesia ..., h. 48. 
Pembiayaan mudharabah membutuhkan kerangka distribusi bagi hasil yang adil dan saling menguntungkan. Pada saat akad penyaluran pembiayaan mudharabah harus terdapat kepastian mengenai prosentase perolehan hasil dari keuntungan usaha yang dibiayai. Bank harus menetapkan mekanisme perhitungan distribusi yang jelas tentang prosentase bagi hasil keuntungan yang kesemuanya lebih merupakan kebijakan bisnis bank yang bersangkutan sehingga dalam pelaksanaannya dapat berbeda dari tiap-tiap bank syariah. Besarnya keuntungan yang dibagikan kepada masing-masing pihak tergantung dari kesepakatan pada saat transaksi atau akad dilaksanakan. ${ }^{4}$

Pada penerapan sistem syariah, tentu mempunyai sistem distribusi bagi hasil yang berbeda dengan perlakuan bank konvensional pada umumnya. Kebutuhan dalam menetapkan metode pengukuran distribusi bagi hasil, terutama pembiayaan mudharabah harus disesuaikan dengan peraturan perbankan dan ketentuan-ketentuan syariah yang telah diatur. ${ }^{5}$

Kebijakan yang ada pada Bank Syariah Mandiri Kcp Sengkang dalam melakukan distribusi menggunakan metode revenue sharing yaitu sistem bagi hasil yang dihitung dari total pendapatan pengelolaan dana tanpa dikurangi dengan biaya pengelolaan dana. ${ }^{6}$ Sehingga para pemilik dana akan menerima tingkat bagi hasil yang lebih besar, maka dari itu keunggulan menggunakan revenue sharing yaitu menarik pihak pemilik dana menginvestasikan dananya pada bank. ${ }^{7}$

Sistem bagi hasil revenue sharing yang diterapkan oleh Bank Syariah Mandiri Kcp Sengkang dianggap lebih maslahat dari pada profit sharing yang mengacu pada fatwa No. 15/ DSN- MUI/IX/ 2000. Perhitungan bagi hasil

\footnotetext{
${ }^{4}$ Kasmir, Dasar-dasar Perbankan ..., h. 8.

${ }^{5}$ Kasmir, Dasar-dasar Perbankan ..., h. 10.

${ }^{6}$ Bank Syariah Mandiri, Standar Prosedur Pembiayaan Business Banking, Ed. 1
} (Rev. 1; 2016), h. 1.

7 Emi Suhartiati, "Sistem Perhitngan Bagi Hasil Pembiayaan Mudharabah", Jurnal Keuangan dan Perbankan, Vol. 19, No. 3, September 2013, h. 18. 
yang diterapkan oleh Bank Syariah Mandiri Sengkang untuk produk pembiayaan mudharabah tidak diterapkan angsuran, tetapi setiap bulannya hanya membayar bagi hasil saja, dan pokok pembiayaan hanya dibayar pada waktu selesai kontrak, sehingga tidak dikenakan denda. ${ }^{8}$

Tehnik perhitungan bagi hasil yang diterapkan oleh Bank Syariah Mandiri Sengkang pada dasarnya sama seperti tehnik bagi hasil yang dipakai dan diterapkan oleh Bank Syariah pada umumnya. Adapun tehnik perhitungan nisbah mudharabah dengan pendekatan Revenue Sharing yang langkah-langkahnya sebagai berikut: a. Menghitung Rasio Harga Pokok Pembiayaan (\% HPP), b. Menghitung Rasio Sales, General, and Adminisrtastion (\%SGA), c. Menghitung Kebutuhan Dana Nasabah, d. Menghitung Proyeksi Bagi Hasil, e. Menghitung Porsi Bagi Hasil, f. Menghitung Realisasi Bagi Hasil. ${ }^{9}$

Berdasarkan uraian tersebut, penulis mengangkat permasalahan ini menjadi obyek penelitian terhadap implementasi nisbah bagi hasil akad pembiayaan mudharabah yang dijalankan oleh Bank Syariah Mandiri Kcp Sengkang. Berdasarkan latar belakang yang telah diuraikan diatas, dapat diambil rumusan masalah sebagai berikut:Apa yang dimaksud dengan Revenue Sharing dan Apakah nisbah bagi hasil pembiayaan mudharabah pada Bank Syariah Mandiri Kcp Sengkang memiliki keunggulan.

\section{METODE}

\section{Jenis dan Pendekatan Penelitian}

Berdasarkan analisisnya, jenis penelitian yang digunakan adalah penelitian kualitatif.

\footnotetext{
${ }^{8}$ www.syariah.com, diakses tanggal 20 Juli, pukul 19.00 WITA.

9 Bank Syariah Mandiri, Standar Prosedur Pembiayaan Business Banking ..., h. 2. 
Karena jenis penelitian ini bisa memberikan data yang akurat dan spesifik terhadap objek penelitian. Adapun yang dimaksud dengan penelitian kualitatif adalah prosedur penelitian yang menghasilkan data dekskriptif berupa kata-kata tertulis atau lisan dari orang-orang atau perilaku yang dapat diamati. ${ }^{10}$

Berdasarkan tempat penelitian, maka jenis penelitian yang digunakan adalah penelitian lapangan.

Penelitian lapangan (field research) yaitu penelitian yang objeknya mengenai gejala-gejala atau peristiwa yang terjadi pada masyarakat yang dilakukan oleh peneliti dengan terjun langsung pada objek penelitian untuk mengumpulkan data dan berbagai informasi. ${ }^{11}$ Dalam hal ini adalah mengenai pelaksanaan nisbah bagi hasil pembiayaan mudharabah dan metode perhitungan bagi hasil (nisbah) yang sebelumnya telah disepakati pada perjanjian awal antara nasabah dengan bank pada Bank Syariah Mandiri Kcp Sengkang.

Pendekatan yang digunakan dalam penelitian ini adalah pendekatan ekonomi syariah yaitu satu alat analisis dalam memahami persoalan ekonomi syariah, khususnya memahami persoalan ekonomi yang terkait dengan pembiayaan.

\section{Instrumen Penelitian}

Adapun instrument penelitian yang digunakan pada penelitian ini yaitu berupa daftar atau lembar pertanyaan atau pedoman wawancara atau interview karena menggunakan metode pengumpulan data yang berupa wawancara atau interview.

${ }^{10}$ Margono, Metode Penelitian Pendidikan (Cet. I; Jakarta: PT. Rineka Cipta, 1997), h 36

11 Hadan Nawawi dan Mimi Martini, Penelitian Terapan, (Yogyakarta: Gadjahmada Unuversity Press), h. 24. 


\section{Sumber dan Pengumpulan Data}

Pengumpulan data dilakukan untuk memperoleh informasi yang dibutuhkan dalam rangka mencapai tujuan penelitian. Dalam hal ini, jenis data yang digunakan pada penelitian ini, yaitu:

a. Data Primer

Data primer adalah sumber data yang langsung memberikan data kepada pengumpul data. ${ }^{12}$ Data primer yang digunakan dalam penelitian ini, diperoleh secara langsung dari obyek/subyek penelitian. Data yang diperoleh dari jawaban informan yang dilengkapi dengan hasil wawancara dari pihak yang berkompeten memberikan informasi sebagai pelengkap dan alat konfirmasi data.

b. Data Sekunder

Menurut Sudjana yang dikemukakan Ardiyana bahwa Data sekunder yaitu data yang diperoleh secara tidak langsung dari sumbernya dan bukan diusahakan sendiri oleh penulis atau peneliti. ${ }^{13}$

Data sekunder yang digunakan dalam penelitian ini, data yang diperoleh dari berbagai sumber baik berupa laporan-laporan, dokumendokumen yang ada di Bank Syariah Mandiri Kcp Sengkang yang tertulis serta dokemen-dokumen dari pihak lain yang mempunyai relevansi dengan objek penelitian ini.

\section{Tehnik Pengumpulan Data}

a. Studi pustaka

Studi pustaka adalah instrumen yang digunakan untuk mengumpulkan data-data dengan menelusuri berbagai jenis kepustakaan untuk memperoleh berbagai teori, konsep, dalil-dalil, variabel, hubungan

12 Sugiyono, Metode Penelitian Kuantitatif Kualitatif dan $R \& D$ (Cet. 21; Bandung: Alfabeta, 2014), h. 225.

${ }_{13}$ Burham Mungim, Penelitian Kualitatif, Komunikasi, Ekonomi, Kebijakan Publik, dan IImu Sosial lainnya, (Jakarta: Prenada Media Group, 2008), h. 68. 
variabel, hasil-hasil penelitian terdahulu yang terkait dengan materi kajian serta data-data sekunder sebagai langkah awal kegiatan penelitian. ${ }^{14}$ Dalam penelitian ini, studi pustaka digunakan untuk memperoleh data-data secara tertulis yang terkait dengan permasalahan yang menunjang dalam penelitian ini.

\section{b. Observasi}

Observasi adalah alat pengumpul data yang sistematis, yang artinya kegiatan observasi mulai dari pencatatan dilakukan menurut prosedur dan aturan-aturan tertentu sehingga dapat diulangi kembali oleh peneliti lain. Selain itu hasil observasi harus memberi kemungkinan untuk menafsirkan sesuatu secara ilmiah. Dalam metode penelitian ini, metode observasi digunakan untuk mengumpulkan dan memperoleh informasi mengenai jenis pembiayaan mudharabah, metode nisbah bagi hasil pada Bank Syariah Mandiri Kcp Sengkang.

c. Wawancara

Wawancara adalah percakapan dengan maksud tertentu. Percakapan itu dilakukan oleh dua pihak, yaitu pewawancara (interviewer) yang mengajukan pertanyaan dan terwawancara (interviewee) yang memberikan jawaban atas pertayaan itu. ${ }^{15}$

Wawancara/interview, yaitu peneliti mengadakan dialog atau tanya jawab langsung untuk mendapatkan informasi yang sebanyak-banyaknya atau setuntas-tuntasnya data yang berkaitan dengan penelitian ini.

\section{Tehnik Analisis Data}

${ }^{14}$ S. Nasution, Metodologi Research Penelitian IImiah, (Jakarta: Bumi Aksara, 2002), h. 61.

${ }^{15}$ Lexy J. Moleong, Metodologi Penelitian Kualitatif, Ed. Revisi (Cet. 22; Bandung: PT Remaja Rosdakarya, 2004), h. 186. 
Untuk menganalisis data-data yang telah dikumpulkan, maka teknik analisis data yang digunakan adalah analisis deskriptif. Adapun teknik analisis deskriptif dengan model analisis interaktif bertujuan untuk menggambarkan, meringkaskan berbagai kondisi, situasi, atau fenomena realitas sosial yang ada di masyarakat yang menjadi obyek penelitian, dan berupaya menarik realitas itu ke permukaan sebagai suatu ciri, karakter, sifat, model, tanda, atau gambaran tentang kondisi, situasi, ataupun fenomena tertentu. ${ }^{16}$

Teknis analisis data yang digunakan dalam penelitian ini adalah mmenggunakan teknik analisis deskriptif. Analisis deskriptif yaitu analisis yang digunakan untuk menganalisis dan mendeskripsikan analisis nisbah bagi hasil pembiayaan mudharabah di Bank Syariah Mandiri Kcp Sengkang.

\section{HASIL DAN PEMBAHASAN}

\section{Pangsa Pasar Pembiayaan Mudharabah}

Bank syariah adalah lembaga intermediasi dan penyedia jasa keuangan yang bekerja berdasarkan etika dan sistem nilai islam, khususnya yang bebas bunga (riba), bebas dari kegiatan spekulatif yang non produktif, bebas dari hal- hal yang tidak jelas (gharar), berprinsip keadilan dan hanya membiayai kegiatan usaha yang halal. ${ }^{17}$

Adanya perkembangan pola pikir masyarakat untuk berbisnis, mengakibatkan pihak bank bersaing dalam menawarkan kerjasama dalam usaha berbisnis. Kerjasama dalam bentuk pembiayaan mudhrabah ini pasti memberikan keuntungan bagi pihak bank dan nasabah. Teknis pembiayaan mudharabah pada perbankan syariah adalah pembiayaan yang ditujukan

${ }^{16}$ Burham Mungim, Penelitian Kualitatif, Komunikasi, Ekonomi, Kebijakan Publik, dan IImu Sosial lainnya ..., h. 69.

17 Ustman, "Prinsip Bagi Hasil Musyarakah Dan Mudharabah Pada Bank Syariah Mandiri Cabang Pamekasan", Jurnal Akuntansi dan Investasi, Vol. 1, No. 1, Mei 2016, h. 33. 
untuk membiayai investasi, modal kerja dan penyediaan fasilitas. Perhitungan bagi hasil menggunakan revenue sharing, dikarenakan resiko yang ditanggung lebih kecil kerugiannya. Pendapatan pemilik modal bergantung pada ketidakpastian usaha dan biaya- biaya yang ditimbulkan dalam proses tersebut. ${ }^{18}$

Mudharabah merupakan salah satu bentuk pembiayaan syariah. Prinsipnya adalah pembagian hasil keuntungan dari sebuah usaha yang dijalankan antara bank sebagai pemilik modal/ dana, dengan pengusaha sebagai pengelolah dana tersebut. Keuntungan yang akan dihasilkan akan dibagi diantara mereka menurut kesepakatan yang ditentukan sebelumnya dalam akad. ${ }^{19}$

Banyaknya bank-bank di Kota dan Kabupaten menjadikan persaingan antar bank tidak bisa dihindarkan. Bank konvensional dan bank syariah sama-sama bersaing dalam mencari pasar. Bahkan persaingan antar satu bank beda KCP pun terjadi. Hal ini menyebabkan pembiayaan Mudharabah di Bank Syariah Mandiri Kcp Sengkang harus bisa bersaing dengan pembiayaan- pembiayaan lain. Kurangnya pengetahuan masyarakat tentang bank syariah khususnya pembiayaan Mudharabah menjadikan bank syariah kalah dengan bank- bank konvensional.

Adapun pangsa pasar pembiayaan mudharabah pada Bank Syariah Mandiri Kcp Sengkang yaitu para kontraktor. Adapun salah satu tujuannya adalah untuk mendirikan sekolah madrasah dan lain- lainnya. ${ }^{20}$

Kendala pembiayaan mudharabah lebih kepada kebijakan bank yang menerapkan tarif tinggi pada pembiayaan mudharabah yang membuat jangkauan dari pembiayaan mudharabah hanya pada kalangan pengusaha

18 Ustman, "Prinsip Bagi Hasil Musyarakah Dan Mudharabah Pada Bank Syariah Mandiri Cabang Pamekasan", Jurnal Akuntansi dan Investasi, ... h. 34.

${ }^{19}$ Muhammad, Manajemen Bank Syariah ..., h. 91.

${ }^{20}$ Mutia, Back Office, wawancara oleh Ainul Hikmah di Bank Syariah Mandiri KCP Sengkang, 4 Oktober 2017. 
besar saja. Oleh sebab itu banyak masyarakat yang tidak tersentuh oleh pembiayaan mudharabah. Prosedur yang ditentukan oleh bank akan menyulitkan nasabah untuk melakukan pengajuan nasabah yang baru akan memulai kegiatan usahanya. Karena para pengusaha baru atau UMKM tidak bisa memenuhi persyaratan- persyaratan yang ditetapkan dalam prosedur pembiayaan. Oleh karena itu, para marketing Bank Syariah Mandiri harus bisa merangkul semua aspek pasar di masyarakat, sehingga terjalin rasa kepercayaan oleh masyarakat. Melakukan pengawasan usaha dengan baik, membina pengusaha baru yang sedang berdiri dan pemberian perhatian yang lebih kepada nasabahnya. ${ }^{21}$

Bank Syariah Mandiri juga membuat promosi yang mana agar pembiayaan mudharabah bisa lebih familiar di masyarakat dan bisa menjadi alternatif utama ketika masyarakat membutuhkan modal usahanya. Promosi yang dilakukan dengan memperbanyak penyebaran brosur dan pihak bank harus membuat strategi pemasaran untuk menghadapi persaingan.

Berdasarkan hal tersebut metode yang diterapkan di Bank Syariah Mandiri Kcp Sengkang tidak sesuai dengan kajian teori yang ada, karena pada pembiayaan mudharabahnya hanya terfokus kepada para pengusaha menengah ke atas. Dana yang dialokasikan untuk pembiayaan mudharabah minimal Rp. 200.000.000,00- sehingga tidak tersentuh oleh pengusaha yang baru memulai usahanya karena tidak adanya kepercayaan yang di berikan pihak bank kepada calon nasabah. Hal inilah yang menjadi faktor kurangnya minat calon nasabah terhadap pembiayaan mudharabah.

\section{Revenue Sharing pada Pembiayaan Mudharabah}

Persaingan bisnis dalam bidang perbankan semakin kompetitif. Berbagai konsep dimunculkan dalam rangka memenuhi kebutuhan nasabah, salah satunya konsep perbankan dengan sistem syariah. Konsep perbankan

${ }^{21}$ Russely Inti Dwi Permata, " Pengaruh Pembiayaan Mudharabah Dan Musyarakah Terhadap Tingkat Profitabilitas”, Jurnal Administrasi Bisnis, Vol. 12, No. 1 Juli 2014, h. 42. 
syariah merupakan kegiatan perbankan dengan dasar syariah islam, yang ciri- cirinya adalah menolak sistem bunga karena dianggap riba, melainkan dengan sistem bagi hasil atau biasa disebut al- mudharabah. Mudharabah merupakan jenis pembiayaan pada perbankan syariah yang prinsipnya adalah pembagian hasil keuntungan sebuah usaha berdasarkan kesepakatan. $^{22}$

Pada bank syariah prinsip mudharabah diterapkan pada produk pembiayaan dan pendanaan. Dalam produk pendanaan, nasabah akan mendapatkan bagi hasil dari pendapatan bank. Sementara bagi hasil dari pembiayaan menjadi keuntungan bank sesuai dengan kerjasama yang telah disepakati di awal akad. Adapun penetuan nisbah bagi hasil didasarkan atas pendekatan revenue sharing.

Revenue pada perbankan syariah adalah hasil yang diterima oleh bank dari penyaluran dana (investasi) ke dalam bentuk aktiva produktif, yaitu penempatan dana bank pada pihak lain. Hal ini merupakan selisih atau angka lebih dari aktiva produktif dengan hasil penerimaan bank. ${ }^{23}$

Perbankan syariah memperkenalkan sistem pada masyarakat dengan istilah Revenue Sharing, yaitu sistem bagi hasil yang dihitung dari total pendapatan pengelolaan dana tanpa dikurangi dengan biaya pengelolaan dana. Jadi jika bank dan nasabah menggunakan skim mudharabah dalam menjalankan pembiayaan modal kerja maka jika usahanya untung, maka harus dibagi berdasarkan porsi bagi hasil. Bagi hasil mudharabah Bank Syariah Mandiri adalah pembiayaan dimana seluruh modal kerja yang

${ }^{22}$ Anan Dwi Saputro, "Sistem Perhitungan Bagi Hasil Pembiayaan Mudharabah Pada PT. Bank Syariah Cabang Malang", Jurnal Administrasi Bisnis, Vol. 21, No. 2 April 2015, h. 47.

${ }^{23}$ Russely Inti Dwi Permata, "Pengaruh Pembiayaan Mudharabah Dan Musyarakah Terhadap Tingkat Profitabilitas", Jurnal Administrasi Bisnis ..., h. 54 
dibutuhkan nasabah ditanggung oleh bank. Keuntungan yang diperoleh dibagi sesuai dengan nisbah yang disepakati. ${ }^{24}$

Lebih jelasnya revenue sharing dalam arti perbankan adalah perhitungan bagi hasil didasarkan kepada total seluruh pendapatan yang diterima sebelum dikurangi biaya- biaya yang telah dikeluarkan untuk memperoleh pendapatan tersebut. Sistem revenue sharing berlaku pada pendapatan bank yang akan dibagikan dihitung berdasarkan pendapatan kotor (gross sales), yang digunakan dalam menghitung bagi hasil untuk produk pendanaan bank.

Dalam revenue sharing, kedua belah pihak akan selalu mendapatkan bagi hasil, karena bagi hasil dihitung dari pendapatan pengelola dana. Sepanjang pengelola dana memperoleh revenue maka pemilik dana akan mendapatkan distribusi bagi hasil. Dari uraian tersebut, terlihat bahwa revenue sharing merupakan pendapatan usaha sebelum dikurangi dengan beban usaha untuk mendapatkan pendapatan tersebut. Maka hasilnya revenue sharing dapat memberikan keuntungan yang lebih besar untuk nasabah. Atas prinsip yang digunakan oleh Bank Syariah Mandiri Kcp Sengkang yaitu revenue sharing, maka Bank Syariah Mandiri Kcp Sengkang mampu untuk bersaing dengan Bank konvensional. Karena nilai yang diterima dapat membagi keuntungan yang besar untuk nasabah. ${ }^{25}$

\section{Keunggulan Nisbah Bagi Hasil Pembiayaan Mudharabah}

Nisbah bagi hasil merupakan prosentase keuntungan yang akan diperoleh saahib al-maal dan mudarib yang ditentukan berdasarkan kesepakatan antara keduanya. Jika usaha tersebut merugi akibat resiko bisnis, bukan akibat kelalaian mudarib, maka pembagian kerugiannya

${ }^{24}$ Mutia, Back Office, wawancara oleh Ainul Hikmah di Bank Syariah Mandiri KCP Sengkang, 4 Oktober 2017.

${ }_{25}$ Bank Syariah Mandiri, Standar Prosedur Pembiayaan Business Banking, Ed. 1 (Rev. 1; 2016), h. 1. 
berdasarkan porsi modal yang disetor oleh masing- masing pihak. Karena seluruh modal yang ditanam dalam usaha mudharib milik saahib al-mal, maka kerugiannya dari usaha tersebut ditanggung sepenuhnya oleh sahib almal. Oleh karena itu, nisbah bagi hasil disebut juga dengan nisbah keuntungan. ${ }^{26}$

Bagi hasil (revenue sharing) adalah bagi hasil yang dihitung dari total pendapatan pengelolaan dana. Dalam sistem syariah pola ini dapat digunakan untuk keperluan distribusi hasil usaha lembaga keuangan syariah.

Adapun keunggulan nisbah bagi hasil (revenue sharing) pembiayaan mudharabah pada Bank Syariah Mandiri Kcp Sengkang adalah dapat meningkatkan investasi dana pihak ketiga pada bank syariah karena jika bank menggunakan sistem perhitungan bagi hasil berdasarkan revenue sharing dimana bagi hasil akan didistribusikan dari total-total pendapatan sebelum dikurangi dengan biaya-biaya maka kemungkinan yang akan terjadi akan tingkat bagi hasil yang akan diterima oleh pemilik dana lebih besar dibandingkan dengan tingkat suku bunga pasar yang berlaku. Kondisi ini akan mempengaruhi para pemilik dana yang mengarahkan investasinya pada bank syariah. ${ }^{27}$

Sedangkan keunggulan nisbah bagi hasil pembiayaan mudharabah bagi mudharib itu sendiri yakni dapat meningkatkan motivasi kerja karena adanya modal yang diberikan oleh bank, selain itu juga dapat mengembangkan skill dan keterampilan yang dimiliki oleh mudharib. ${ }^{28}$

Berdasarkan hasil penelitian yang dilakukan pada Bank Syariah Mandiri Kcp Sengkang bahwa modal yang ditanamkan investor/nasabah kepada bank memiliki keuntungan, karena pihak investor/nasabah menerima

${ }^{26}$ Muhammad, Teknik Perhitungan Bagi Hasil di Bank Syariah, (Yogyakarta: UII Press, 2012), h. 26.

${ }^{27}$ Emi Suhartiati, "Sistem Perhitngan Bagi Hasil Pembiayaan Mudharabah", Jurnal Keuangan dan Perbankan ..., h. 19.

${ }_{28}$ Mutia, Back Office, wawancara oleh Ainul Hikmah di Bank Syariah Mandiri KCP Sengkang, 4 Oktober 2017.

Jurnal Ilmiah Al Tsarwah Program Magister Program Studi Ekonomi Syariah 
pendapatan dari modal yang dikelola mudarib tanpa dikurangi dengan biayabiaya. Sehingga bank selaku sahib al-mal menerima porsi bagi hasil sesuai dengan kesepakatan yang dilakukan dengan mudarib, dan biaya-biaya yang dikeluarkan untuk pengalokasian dana pada pembiayaan mudharabah ditanggung oleh mudharib.

\section{KESIMPULAN DAN SARAN}

\section{Kesimpulan}

Berdasarkan hasil penelitian dan pembahasan diatas, maka dapat ditarik kesimpulan bahwa: Revenue Sharing adalah sistem bagi hasil yang dihitung dari total pendapatan pengelolaan dana tanpa dikurangi dengan biaya pengelolaan dana. Jadi jika bank dan nasabah menggunakan skim mudharabah dalam menjalankan pembiayaan modal kerja maka jika usahanya untung, maka harus dibagi berdasarkan porsi bagi hasil. Bagi hasil mudharabah Bank Syariah Mandiri adalah pembiayaan dimana seluruh modal kerja yang dibutuhkan nasabah ditanggung oleh bank. Dengan menggunakan metode revenue sharing, adapun keunggulan nisbah bagi hasil pembiayaan mudharabah pada Bank Syariah Mandiri Kcp Sengkang adalah dapat meningkatkan investasi dana pihak ketiga pada bank syariah yakni dimana bagi hasil akan didistribusikan dari total-total pendapatan sebelum dikurangi dengan biaya-biaya maka kemungkinan yang akan terjadi akan tingkat bagi hasil yang akan diterima oleh pemilik dana akan lebih besar dibandingkan dengan tingkat suku bunga 


\section{Saran}

Berdasarkan kesimpulan diatas maka dapat disarankan sebagai berikut, Bagi pihak bank sebaiknya tidak terfokus kepada kalangan pengusaha menengah keatas saja dalam mengalokasikan pembiayaan mudharabah akan tetapi juga pihak bank memberikan kepercayaan kepada pihak yang baru memulai usahanya atau UMKM melalui pembinaan usaha dan memberikan perhatian yang lebih kepada calon nasabahnya. Sehingga dapat menarik pihak investor dalam menanamkan modalnya.

\section{DAFTAR PUSTAKA}

Antonio Muhammad Syafi'i, Bank Syariah dari Teori ke Praktik. Cet. 1; Jakarta: Gema Insani, 2001.

Arifin Zainul. Memahami Bank Syariah, Lingkup, Peluang, Tantangan, dan Prospek.

Cet. 1; Jakarta : Alvabet, 2000.

Arikunto Suharsimi, Prosedur Penelitian : Suatu Pendekatan Praktek,. Jakarta: Rineka Cipta, 2006.

Ascarya, Akad dan Produk Bank Syariah. Cet. IV; Jakarta: Rajawali Pers, 2013.

Bank Syariah Mandiri, Standar Prosedur Pembiayaan Business Banking. Rev. 1; 2016.

Fadhilla Novi. "Analisis Pembiayaan Mudharabah dan Mudharabah Terhadap Laba Bank Syariah Mandiri”. Jurnal Riset Akuntansi dan Bisnis, Vol. 15, No. 1, Maret 2015.

Hasan Iqbal, Analisis Data Penelitian dengan Statistik. Cet. 4; Jakarta: Bumi Aksara, 2009.

Ikit, "Analisis Pelaksanaan Sistem Pembiayaan Bagi Hasil pada Bank Umum Syariah di Daerah Istimewa Yogyakarta”. Skripsi, UIN Sunan Kalijaga Yogyakarta, 2012.

Iska H. Syukri, Sistem Perbankan Syariah di Indonesia. Cet. 1; Yogyakarta: Fajar Media Press, 2012. 